\title{
Pull-Out Resistance of Sand-Geosynthetics Reinforcement
}

\author{
M. K. A. Ismail ${ }^{1 *}$, M. I. Joohari ${ }^{1}$, A. Habulat ${ }^{1}$, F. A. Azizan ${ }^{1}$ \\ ${ }^{1}$ Faculty of Civil Engineering, \\ Universiti Teknologi MARA, Cawangan Pulau Pinang, 13500 Permatang Pauh, Pulau Pinang, MALAYSIA \\ *Corresponding Author
}

DOI: https://doi.org/10.30880/ijie.2021.13.03.010

Received 20 December 2020; Accepted 01 May 2021; Available online 06 June 2021

\begin{abstract}
Geosynthetics are widely used in earth retaining structures such as steep slope and earth retaining wall. The stability of the earth retaining structures depends on the interaction between geosynthetics and soil at the reinforced area known as reinforcement mechanism. The reinforcement mechanism of the soil reinforced structure usually difficult to be analysed thoroughly. It is because the preliminary study on the pull-out resistance and durability of the reinforcement material is not taking into account before it has been used to the site location especially in Malaysian practises. Less supervision and the assessment after the installation of the reinforcement materials also contributed to the failure of the soil reinforcement. In this paper, the laboratory model was used to imply the real condition of the soil reinforced structure using pull-out test. A standard pull-out test was carried out by using geotextile and geogrid reinforcing elements embedded into silica sand of size $\mathrm{D}_{50}=1.357 \mathrm{~mm}$ and $\mathrm{D}_{50}=0.571 \mathrm{~mm}$ subjected to normal pressures of $100 \mathrm{kPa}, 150 \mathrm{kPa}$ and $200 \mathrm{kPa}$. Comparative result and analysis showed that the geotextile reinforcement give more resistance rather than geogrid reinforcement under high normal pressure.
\end{abstract}

Keywords: Geosynthetics, interaction, reinforcement mechanism, pull-out test

\section{Introduction}

Geosynthetic is related to many functions and usages. According to Pinto [1] and Ennio et al. [2] geosynthetics such as geotextiles and geogrids are broadly used as reinforcement materials and stabilization. The design of the reinforcement always related to the ultimate tensile strength of the geosynthetics and it depends on the materials itself. Bao [3] mentioned that, the study on the reinforcement mechanism and the relevant design theory are much backward relative to the engineering application. Omer [4] reported that, several failure modes are considered before installation of the geosynthetics in order to suit internal and external stability. External stability refers to the sliding and overturning failures which are determined as one unit rigid during analysis. It is easy to measure the external stability compared to the internal stability using the factor of safety analysis. However, the internal stability refers to the reactions of the geosynthetics with the soil media. This reaction caused by the friction forces between soil particles and tensile strength of the geosynthetics. When tensile force in reinforcement exceeds friction force between the reinforcement and soil, the reinforcement is pulled out of the soil mass, resulting in a pull-out failure. If the tensile force in the reinforcement becomes larger than the geosynthetic, it would lead to rupture failure. It is parallel with Alfaro [5] that found the internal stability of the geosynthetic-reinforced soil is classified for two common failure mode which is rupture due to tensile over stressing in the high-stress condition and pull-out failures. Pull-out failure occurs whenever the slippage of soil-geosynthetics interaction in the low-stress condition within the interface region. Therefore, the difficulty of the internal stability has encouraged many researchers to explore and enhance the behavior of the geosynthetics and its effects to the soil structure. 


\section{Pull-Out Test}

According to ASTM D6706-01 [6] and Yin [7], pull-out test is a method used to identify the interaction of geosynthetics and soil structure induced by surcharge load. The interaction is related to maximum pull-out force (kN) required with respect to displacement $(\mathrm{mm})$ of geosynthetics. The pull-out resistance, Pr also has been identified as shear resistance values of geosynthetics per contact area due to different normal pressure. A pull-out device that has been used for this research is modified by previous study done by [8].

\subsection{Model Set-Up}

The model set up of pull-out test machine is fabricated and conducted accordance to ASTM D6706-01 [6]. It is made by mild steel and Perspex sheet whereby the size of a box is $400 \mathrm{~mm}$ (width) x $550 \mathrm{~mm}$ (height) x $700 \mathrm{~mm}$ (length). This box is filled up with the soil sample and embedded geosynthetics until reached $400 \mathrm{~mm}$ of height. There is a $10 \mathrm{~mm}$ thick steel plate at the top of the box used to compress the soil sample with desired pressure [7]. The pressure was generated by a hydraulic power pack attached with S-type load cell. Meanwhile, the horizontal movement was generated with an electric motor that pulled the geosynthetics sample at constant rate of $2 \mathrm{~mm} / \mathrm{min}$ [6]. Similar to the vertical load, the horizontal force induced by movement of geosynthetics has also been recorded by $\mathrm{S}$-type load cell. Furthermore, the displacement of the geosynthetics leads to pull out being measured using the Linear Variable Differential Transducer (LVDT). All the measured reading of load and displacement were directly recorded and saved in the data logger. Fig. 1 shows the set-up apparatus of geosynthetics pull out test.

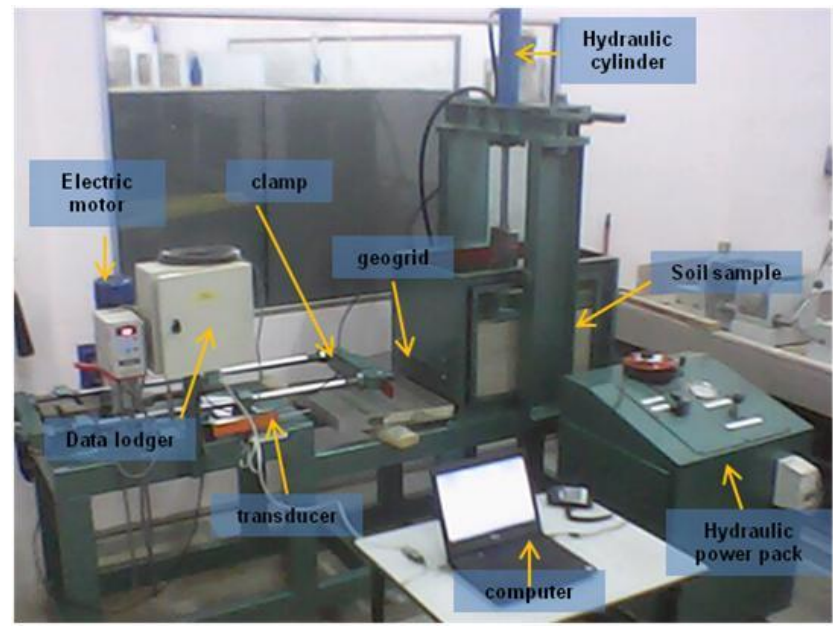

Fig. 1 - Set-up apparatus of geosynthetics pull-out test

\subsection{Test Procedure}

The test started with sample preparation whereby the geosynthetics were cut into a square size of $860 \mathrm{~mm}$ (length) x $280 \mathrm{~mm}$ (width). The dry sand sample was poured, 1 reached $200 \mathrm{~mm}$ from the bottom of the box. This is to allow the installation of the geosynthetics in the middle of the soil sample. One end of the geosynthetics is clamped, and another one is freely laid on the sand sample. Fig. 2 shows the typical installation method of geosynthetics. All equipment were calibrated before test was conducted. The calibrations were made by an appointed supplier.

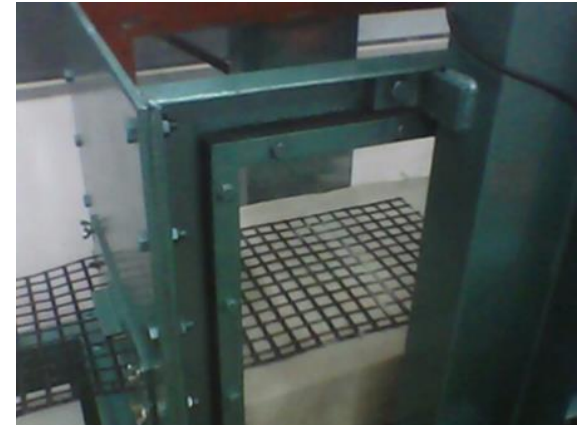

(a)

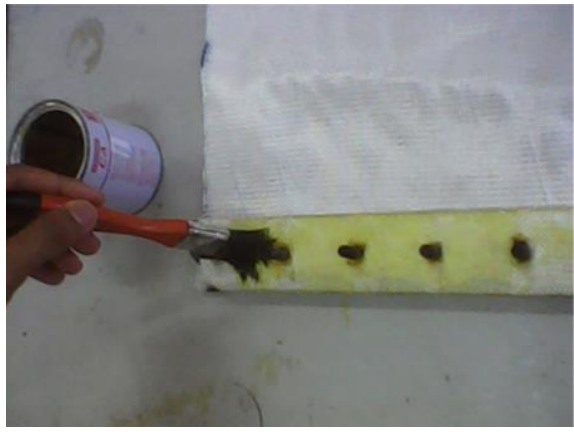

(b)

Fig. 2 - (a) installation of geogrid; (b) gluing of the geotextile 
The sand was again poured into the pull-out box until achieved $400 \mathrm{~mm}$ of height. The sand sample is precompacted $100 \mathrm{~mm}$ thick for each layer to provide adequate compaction [9]. Next, the top plate is lowered down and the sand is compressed to achieve desired pressure, which are $100 \mathrm{kPa}, 150 \mathrm{kPa}$ and $200 \mathrm{kPa}$. Pull out process was conducted just after compression has achieved the desired value. The geosynthetics is pulled out at rate of $2 \mathrm{~mm} / \mathrm{min}$ whilst displacement and pull-out force is recorded in a data logger (model: CR 1000). The test was stopped because the geosynthetics has achieved the maximum pull-out force, or it has failed due to rupture. The additional process was made for geotextile-pull-out test. The geotextile was wrapped and glued with the clamp for three rolls. After 30 minutes of being dried, the geotextile was drilled precisely to the bolds' holes. There were six bolds which were used to tie up the clamp. Again, the geotextile was spread with glue in order to give the uniform distribution of load at the clamp [6]. In addition, the glued area may prevent geotextile to fail at the clamp. After geotextile has been tied to pull-out clamp, it was left to dry for 30 minutes to get a strong binding.

\subsection{Material and Sample Preparation}

Geosynthetics that has been used as reinforcement material is geogrid and geotextile. Previous researchers also used geogrid as a material to define the reaction of reinforcement mechanism. McDowell [10] and Yan [11] has studied on the behavior of soil reinforced-geogrid experimentally and numerically. Meanwhile, geotextile has been installed for separation, reinforcement of soil and also for filtration purposes. The reinforcement materials were cut for $280 \mathrm{~mm}$ (width) x $860 \mathrm{~mm}$ (length). The dimension of pull out box is just $700 \mathrm{~mm}$ in length and $400 \mathrm{~mm}$ in width. The extra $160 \mathrm{~mm}$ of length is used to tie up the geosynthetics to the clamp. These two reinforcement materials are shown in Fig. 3. The description on the materials properties are explained in Table 1. Soil samples was used is silica sands which is supplied by L\&T Mineral Sdn. Bhd, Bestari Jaya, Selangor. Silica sands were classified based on the mean size distribution or $\mathrm{D}_{50}$ as shown in Fig. 4. Two different size of $\mathrm{D}_{50}$ was highlighted purposely to determine the effect of particles size and friction angle to pull-out resistance. Table 2 describes properties of silica sand.

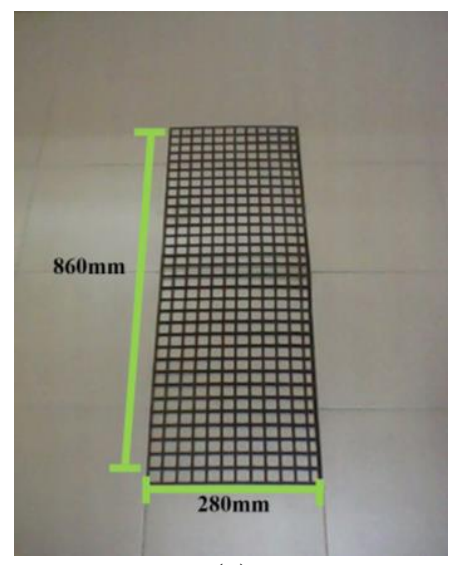

(a)

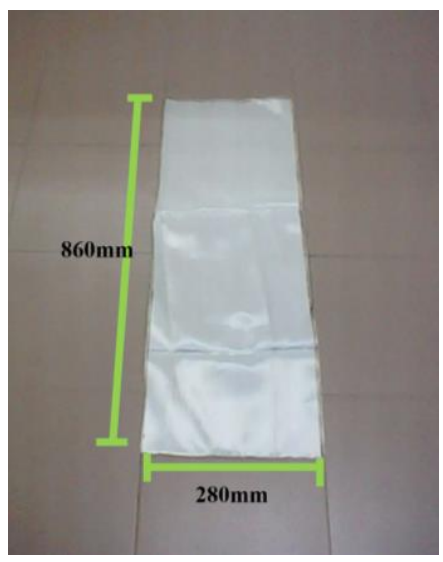

(b)

Fig. 3 - (a) biaxial geogrid; (b) woven geotextile

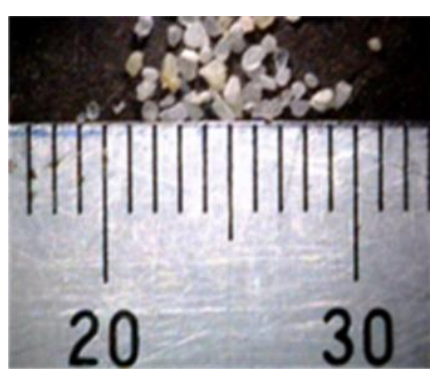

(a)

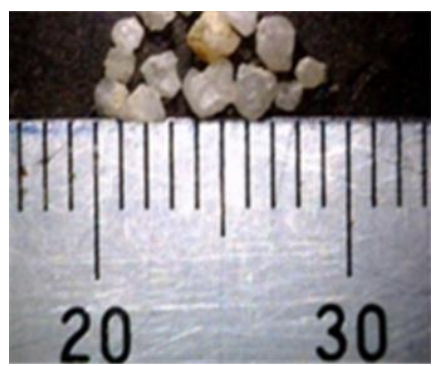

(b)

Fig. 4 - (a) silica sand, $D_{50}=0.571 \mathrm{~mm}$; (b) silica sand, $D_{50}=1.357 \mathrm{~mm}$ 
Table 1 - Description of geosynthetics supplied by Tencate Geosynthetics, Malaysia

\begin{tabular}{lclll}
\hline $\begin{array}{l}\text { Geosynthetics } \\
\text { Products }\end{array}$ & $\begin{array}{c}\text { Tensile strength } \\
(\mathbf{k N / m})\end{array}$ & Type of product & Raw material & Main function \\
\hline $\begin{array}{l}\text { Tencate Miragrid } \\
\begin{array}{l}\text { GX (20/20) } \\
\text { (Geogrids) }\end{array}\end{array}$ & $20-21$ & $\begin{array}{l}\text { Biaxial } \\
\text { geogrid }\end{array}$ & $\begin{array}{l}\text { Polymeric coated } \\
\text { high tenacity PET yarns }\end{array}$ & Reinforcement \\
\hline $\begin{array}{l}\text { Tencate Polyfelt } \\
\text { Geolon PET (100) } \\
\text { (Geotextiles) }\end{array}$ & $100-110$ & Woven & High tenacity PET yarns & $\begin{array}{l}\text { Separator and } \\
\text { reinforcement }\end{array}$ \\
\hline
\end{tabular}

Table 2 - Properties of silica sand

\begin{tabular}{ccccc}
\hline $\begin{array}{c}\text { Mean size distribution } \\
\left(\mathbf{D}_{\mathbf{5 0}}\right), \mathbf{~ m m}\end{array}$ & Soil classification & $\begin{array}{c}\text { Particles density, } \\
\left(\boldsymbol{\rho}_{\boldsymbol{s}}\right) \mathbf{k g} / \mathbf{m}^{\mathbf{3}}\end{array}$ & $\begin{array}{c}\text { Relative } \\
\text { density }(\boldsymbol{\%})\end{array}$ & $\begin{array}{c}\text { Friction angle, } \\
(\mathbf{d e g r e e s})\end{array}$ \\
\hline 1.357 & Poorly Graded SAND,SP & 2.63 & 60 & 52.6 \\
\hline 0.571 & Poorly Graded SAND,SP & 2.64 & 64 & 46.8 \\
\hline
\end{tabular}

\subsection{Tensile Strength of Geosynthetics}

The tensile strength of the geotextile was conducted according to the [12]. Meanwhile, the tensile strength of the geogrid was conducted according to the [13]. The tensile strength of geosynthetics was calibrated with the manufacturer's standard values as shown in Table 3. There are three samples of geosynthetics were tested for each geogrid and geotextile respectively. The average value of the tensile strength for geotextile is $108.97 \mathrm{kN} / \mathrm{m}$. It has $0.94-$ $8.23 \%$ different of tensile strength. The identified tensile strength has located in the range of the manufacturer standard. Meanwhile, the geogrid samples have given an average tensile strength at $22.34 \mathrm{kN} / \mathrm{m}$. It has $3.18-7.79 \%$ different of tensile strength. The average tensile strength for geogrid has exceeded the manufacturer's range value.

Table 3 - Tensile strength of geosynthetics

\begin{tabular}{llll}
\hline \multirow{2}{*}{ Geosynthetics } & \multicolumn{2}{c}{ Tensile strength, kN/m } & Percentage \\
\cline { 2 - 3 } & Manufacturer & Identified & different $\%$ \\
\hline Woven Geotextile & $100-110$ & 108.97 & $0.94-8.23$ \\
\hline Biaxial Geogrid & $20-21$ & 21.69 & $3.18-7.79$ \\
\hline
\end{tabular}

\section{Result and Discussion}

The reinforcement mechanism of sand-geosynthetics interaction due to pull-out is illustrated in Fig. 5. The normal pressure has induced the interlocking effect between sand particles and geosynthetic, and then formed the rigid interaction. The geosynthetic try to resist the pull-out force and shear force is increased significantly with respect to displacement of geosynthetic. The geosynthetics is pulled until it has failed due to pull-out or rupture failure. The cumulative shear force along the interface region called as shear zone. Reference [5] identified this phenomenon as shear band.

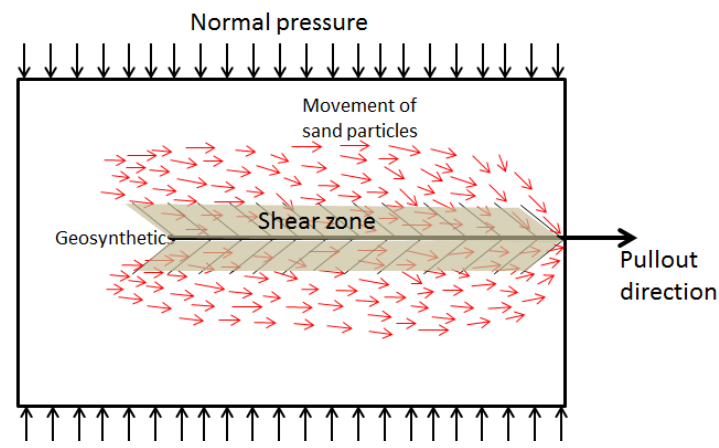

Fig. 5 - Reinforcement mechanism of sand-geosynthetics at interface region 


\subsection{Sand-Geosynthetics Interaction Behavior}

Fig. 6 shows the results of pull-out force versus displacement of geotextiles and geogrids in $\mathrm{D}_{50}=1.357 \mathrm{~mm}$ sand. In additional, the pull-out resistance, $\mathrm{Pr}$ was calculated as shear resistance values of geosynthetics per contact area. $\mathrm{Pr}$ value also used to define the maximum tensile strength of the geosynthetics. Comparatively, the maximum pull-out force at failure is $39.1 \mathrm{kN}$ which was recorded by sand- geotextile interaction at $200 \mathrm{kPa}$ whereas, the minimum reading pull-out force at failure is $8.67 \mathrm{kN}$ which was recorded by sand-geogrid interaction at $100 \mathrm{kPa}$ of normal pressure. The percentage different is $78 \%$ with respect to $35.27 \mathrm{~mm}$ and $60.79 \mathrm{~mm}$ of displacement respectively. Sand-geogrid interaction has recorded a high value of pull-out force at $11.52 \mathrm{kN}$ under $200 \mathrm{kPa}$ of normal pressure. The effect of this condition has made the geogrid ruptured during the pull-out. This is due to the reaction of transverse ribs that interlocked with the sand particles in dense condition. The passive resistance against transverse ribs encouraged the load transfer mechanism at interface region [14]. Furthermore, it is related to the production of the geogrid, whereby the maximum tensile strength is $(20-21 \mathrm{kN} / \mathrm{m})$ only. It is predicted to have a large maximum pull-out force if the geogrid sample has a high value of tensile strength. At $100 \mathrm{kPa}$ and $150 \mathrm{kPa}$, most of the geogrids samples do not fail by rupture in sand. Its failure was due to poor interaction of geogrid with sand particles at the reinforced zone. Poor interaction relates to the failure of frictional forces between sand-to-sand and also sand-to-geogrid's surface. Furthermore, it also related to the transverse ribs of geogrid. This is caused by the reaction of transverse ribs that pass through the assembled sand particles and encouraged sand particles to slide and rotated accordingly to the mobilized geogrid. It similar with [15] proves that the reaction of interlocking by geogrid's ribs is functioning well whenever geogrid is embedded in denser particles and gaining the shear strength of reinforced soil structure. Similar to geotextile sample, it has failed by rupture at $200 \mathrm{kPa}$ due to a large contact area between sand to geotextile. The large contact area at high densification has increased shear resistance at the reinforced zone. At a dense condition, woven geotextile also allowed the sand particles to penetrate the geotextile's surface and interlocked between the yarns. It is also related to the high tensile strength of the geotextile $(100-110 \mathrm{kN} / \mathrm{m})$ which is five times larger than the geogrid has. As a result, the combination of large contact area, interlocking and high tensile strength at constant densification has produced a great interface effect at reinforced zone. Fig. 7 illustrates the rupture failure of geotextile and geogrid at $200 \mathrm{kPa}$ of normal pressure. Fig. 8 illustrates the results of pull-out force versus displacement of geotextiles and geogrid in $\mathrm{D}_{50}=0.571 \mathrm{~mm}$ sand. Geotextile sample has recorded $30.67 \mathrm{kN}$ of peak force failure at $52.21 \mathrm{~mm}$ of displacement with respect to $200 \mathrm{kPa}$ of normal stress. Comparatively, pull-out force increased by $13.63 \%$ if the normal pressure increased from $100 \mathrm{kPa}$ to $200 \mathrm{kPa}$, whereas, at $100 \mathrm{kPa}$ to $150 \mathrm{kPa}$ and $150 \mathrm{kPa}$ to $200 \mathrm{kPa}$ of normal stress, pull-out forces differ by $2 \%$ and $11.87 \%$ respectively. It is parallel with [16] and [17], the pull-out force increases with increasing normal pressure. For geogrid, the maximum pull-out force at failure is stated by $200 \mathrm{kPa}$ of normal stress which is $11 \mathrm{kN}$ at $51.51 \mathrm{~mm}$ displacement.

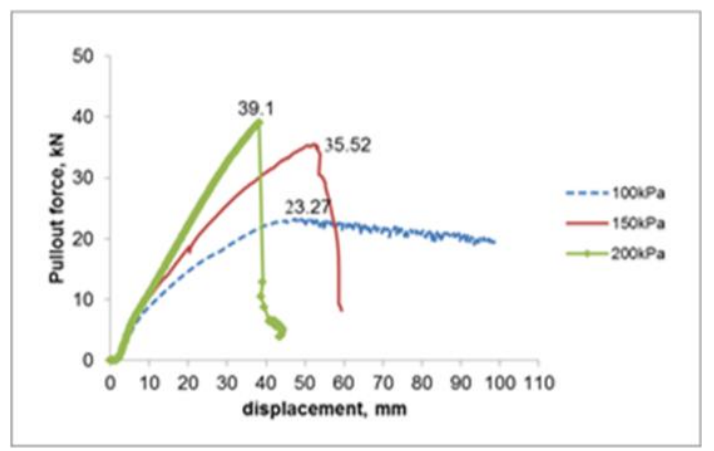

(a)

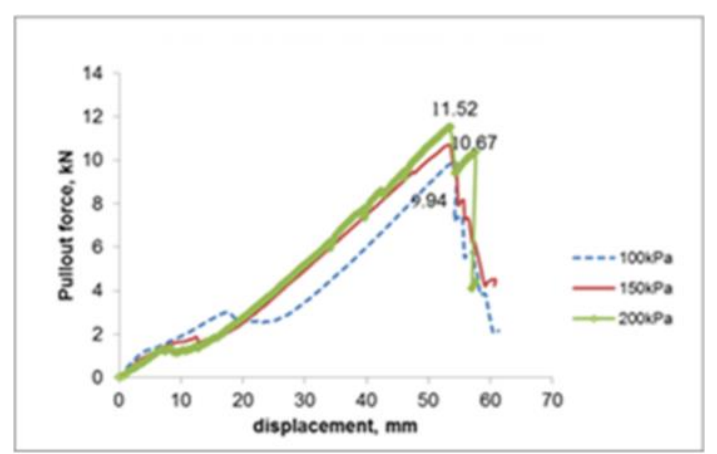

(b)

Fig. 6 - (a) pull-out of geotextile in $\left(D_{50}=1.357 \mathrm{~mm}\right)$; (b) pull-out of geogrid in $\left(D_{50}=1.357 \mathrm{~mm}\right)$

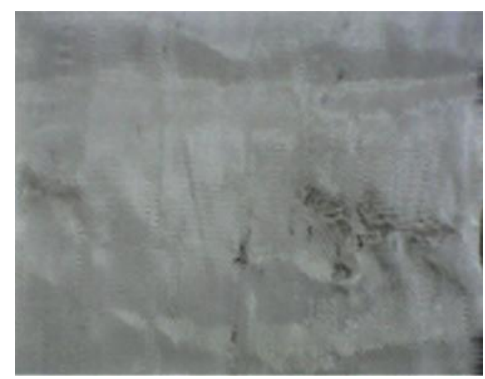

(a)

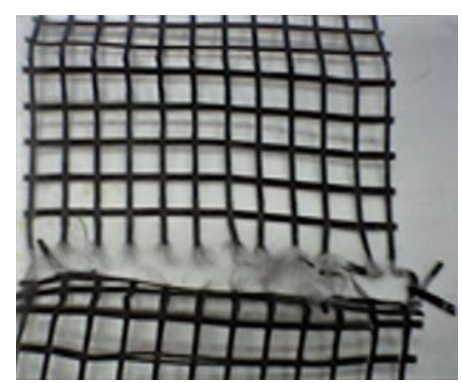

(b)

Fig. 7 - (a) rupture failure of geotextile; (b) rupture failure of geogrid 


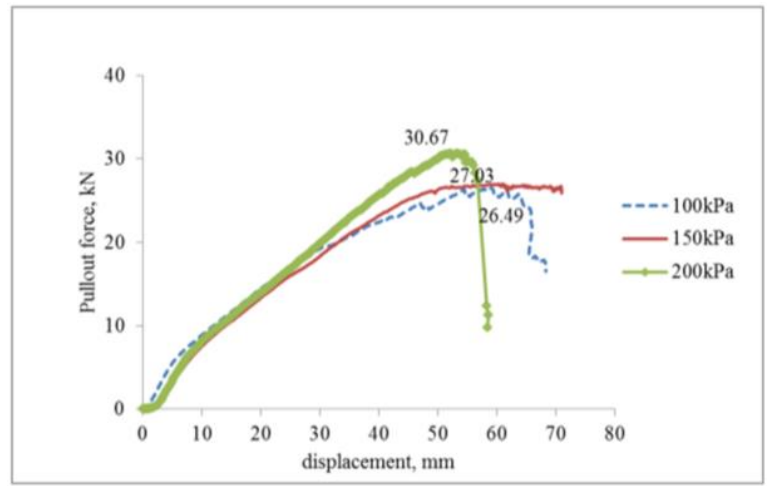

(a)

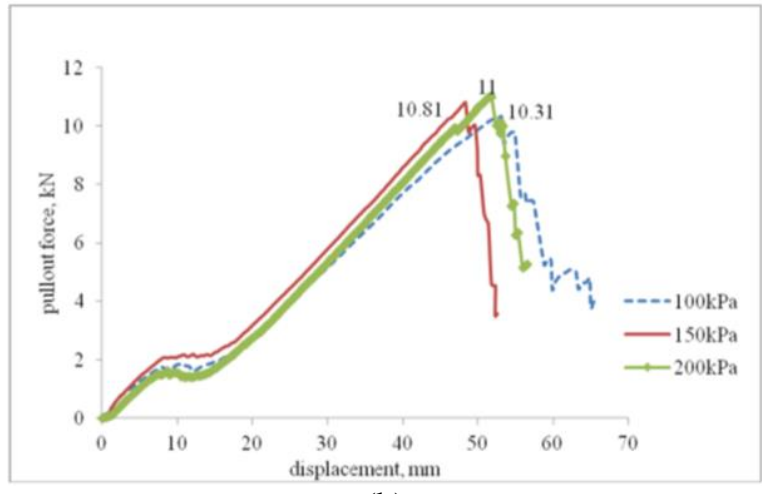

(b)

Fig. 8 - (a) pull-out of geotextile in $\left(D_{50}=0.571 \mathrm{~mm}\right)$; (a) pull-out of geogrid in $\left(D_{50}=0.571 \mathrm{~mm}\right)$

Fig. 9 shows the pull-out resistance, Pr of geotextile and geogrid in $\mathrm{D}_{50}=1.357 \mathrm{~mm}$ and $\mathrm{D}_{50}=0.571 \mathrm{~mm}$. Pr of geosynthetics was identified according to [4]. For $\mathrm{D}_{50}=1.357 \mathrm{~mm}$, geotextile gave a high value of resistance at $200 \mathrm{kPa}$ pressure at which the resistance is $139.64 \mathrm{kN} / \mathrm{m}$ and Pr has exceeded the maximum tensile strength. Meanwhile, for $\mathrm{D}_{50}=0.571 \mathrm{~mm}$, Pr is recorded at $94.61 \mathrm{kN} / \mathrm{m}$ at $100 \mathrm{kPa}$ of normal stress. It is followed by $150 \mathrm{kPa}$ and $200 \mathrm{kPa}$ of normal stress whereby $\operatorname{Pr}$ has recorded at $96.54 \mathrm{kN} / \mathrm{m}$ and $109.54 \mathrm{kN} / \mathrm{m}$ respectively. Refer from the result, the resistance values of geotextile in $\mathrm{D}_{50}=0.571 \mathrm{~mm}$ for three different normal pressures indicate that geotextile can be loaded with more normal pressure as long as the resistance value does not exceed $110 \mathrm{kN} / \mathrm{m}$ of maximum tensile strength. Meanwhile, for geogrids in $\mathrm{D}_{50}=1.357 \mathrm{~mm}$ and $\mathrm{D}_{50}=0.571 \mathrm{~mm}$ sand. The resistances for three different normal stresses were not too obvious. Pr has produced $19.68 \mathrm{kN} / \mathrm{m}$ at $100 \mathrm{kPa}$ of normal stress. It is followed by $150 \mathrm{kPa}$ and $200 \mathrm{kPa}$ which produced $20.67 \mathrm{kN} / \mathrm{m}$ and $21 \mathrm{kN} / \mathrm{m}$ of Pr respectively. Pr values for $150 \mathrm{kPa}$ and $200 \mathrm{kPa}$ is in range $(20-21 \mathrm{kN} / \mathrm{m})$ of tensile strength of geogrid. However, the geogrid samples still in good condition without broken off although the Pr value just attained the ultimate tensile strength. It is predicted that geogrid samples will fail if the normal pressure increase more than $200 \mathrm{kPa}$.Sand-geotextile interaction has recorded high values of pull-out force at $100 \mathrm{kPa}, 150 \mathrm{kPa}$ and $200 \mathrm{kPa}$ compared to sand-geogrid interaction. It can be concluded that, the increment of the pull-out resistance, $\mathrm{Pr}$, is directly proportional to the maximum pull-out force associated with increment of normal pressure.

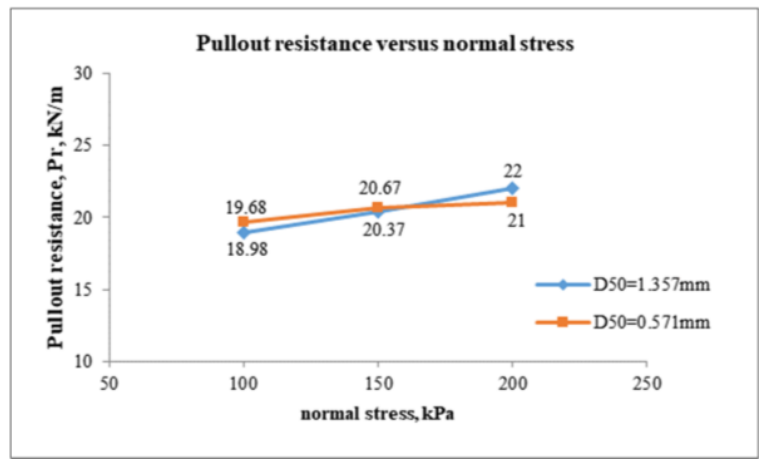

(a)

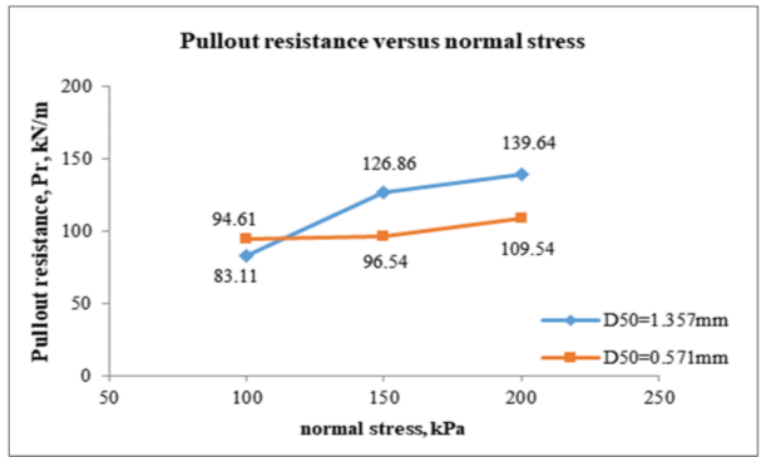

(b)

Fig. 9 - (a) Pr of geotextile in silica sand; (b) Pr of geogrid in silica sand

\section{Conclusion}

In conclusion, the pull-out test of geosynthetics has demonstrated the pull-out resistance of Sand-Geosynthetics reinforcement. Comparatively, in $\mathrm{D}_{50}=1.357 \mathrm{~mm}$, for geotextile, the peak force at failure is $39.1 \mathrm{kN}$ at $38.27 \mathrm{~mm}$ displacements, whereas, for geogrid, the peak force at failure is $11.52 \mathrm{kN}$ at $53.55 \mathrm{~mm}$ displacement. The percentages differ is $70.54 \%$. Meanwhile, in $\mathrm{D}_{50}=0.571 \mathrm{~mm}$, the pull-out force at failure is recorded at $30.67 \mathrm{kN}$ for geotextile and $11 \mathrm{kN}$ for geogrid due to $200 \mathrm{kPa}$ of normal pressure. The pull-out forces at failure keep reducing with respect to 150 $\mathrm{kPa}$ and $100 \mathrm{kPa}$ of normal pressure and caused the geogrid and geotextile just failed due to sliding. The large contact area at high densification has increased shear resistance at the reinforced zone. At a dense condition, woven geotextile allowed the sand particles to penetrate the geotextile's surface and interlocked between the yarns. It is caused by the influenced of normal pressure that provided a different densification of sand structure. The denser sand structure, the higher force required to pull-out the geotextile. Moreover, the different size of the soil media obviously contributed in giving the maximum pull-out resistance. The bigger sizes of sand particles, the higher shear resistance were produced 
[15], [18]. It is related to silica sand $\mathrm{D}_{50}=1.357 \mathrm{~mm}$ which has higher friction angle compared to silica sand $\mathrm{D}_{50}=0.571$ $\mathrm{mm}$. The friction angle of $\mathrm{D}_{50}=1.357 \mathrm{~mm}$ has $11 \%$ higher than $\mathrm{D}_{50}=0.571 \mathrm{~mm}$ of silica sand. Yet, this laboratory testing is useful to be applied for preliminary study of soil reinforcement characteristics before the installation of the reinforcement on specific area. Through several pull-out tests, the engineer may find the suitable geosynthetics materials and optimize the design of soil reinforcement.

\section{Acknowledgement}

Highly gratitude is given to the Faculty of Civil Engineering, Universiti Teknologi MARA, Cawangan Pulau Pinang, Malaysia and Faculty of Civil Engineering, Universiti Teknologi MARA, Shah Alam, Selangor, Malaysia.

\section{References}

[1] Pinto M. I. M. (2003). Applications of geosynthetics for soil reinforcement. Ground Improvement, 7, 61-72.

[2] Ennio M. P., Fumio T., Richard J. B., Peter E. S. \& Jorge G. Z. (2008). Advances in geosynthetics materials and applications for soil reinforcement and environmental protection works. The Electronic Journal of Geotechnical Engineering, 13, 1-38.

[3] Bao C. (2003). Study on the interaction behavior of geosynthetics and soil in China. Chinese Journal of Geotechnical Engineering, 25, 129-134.

[4] Omer B. (2009). Failure mechanisms governing reinforcement length of geogrid reinforced soil retaining wall. Engineering Structures, 31, 1967-1975.

[5] Alfaro M. C. \& Pathak Y. P. (2005). Dilatant stresses at the interface of granular fills and geogrid strip reinforcement. Geosynthetics International, 12(5), 239-252.

[6] ASTM D6706-01 (2007). Standard Test Method for Measuring Geosynthetic Pull-Out Resistance in Soil. ASTM International.

[7] Yin G., Wei Z., Wang J. G., Wan L. \& Shen L. (2008). Interaction characteristics of geosynthetics with fine tailings in pull-out test. Geosynthetics International, 15(6), 428-436.

[8] Khedkar M. S. \& Mandal J. N. (2009). pull-out behaviour of cellular reinforcements. Geotextiles and Geomembranes, 27, 262-271.

[9] Marolo C. A., Norihiko M. \& Dennes T. B. (1995). Soil-geogrid reinforcement interaction by pull-out and direct shear tests. Geotechnical Testing Journal, 18, 157-167.

[10] McDowell G. R., Harireche O., Konietzky H., Brown S. F. \& Thom N. H. (2006). Discrete element modelling of geogrid-reinforced aggregates. Proceedings of the Institution of Civil Engineers Geotechnical Engineering, 159, 35-48.

[11] Yan S., Feng S. \& Barr B. (1998). Finite-Element modeling of soil-geogrid interaction dealing with the pull-out behavior of geogrids, Acta Mechanica Sinica, 14(4), 371-382.

[12] ASTM D4595-11 (2011). Standard Test Method for Tensile Properties of Geotextiles by the Wide-Width Strip Method. ASTM International.

[13] ASTM D6637-11 (2011). Standard Test Method for Determining Tensile Properties of Geogrids by the Single or Multi-Rib Tensile Method. ASTM International.

[14] Ana C. C. F. S., Denise M. S. G. \& Alberto S. F. J. S. (2009). Displacement and load transfer mechanisms of geogrids under pull-out condition. Geotextiles and Geomembranes, 27, 241-253.

[15] Mehrjardi G. T., Ghanbari A. \& Mehdizadeh H. (2016). experimental study on the behaviour of geogridreinforced slopes with respect to aggregate size. Geotextiles and Geomembranes, 44, 862-871.

[16] Zhijie W., Felix J. \& Martin Z. (2016). Experimental and DEM investigation of geogrid-soil interaction under pull-out loads. Geotextiles and Geomembranes, 44, 230-246.

[17] Lopes M. L. \& Silvano R. (2010). Soil/Geotextile interface behaviour in direct shear and pull-out movements, Geotech Geological Engineering, 28, 791-804.

[18] Wang J., Liu F. Y., Wang P. \& Cai Y. Q. (2016). Particle size effects on coarse soil-geogrid interface response in cyclic and post-cyclic direct shear tests. Geotextiles and Geomembranes, 44, 854-861. 